\title{
Effects of Different Land Status on Conservation Land and Income of Upland Rice Farming in Mausambi Village, Maurole Subdistrict, Ende Regency
}

\author{
Willybrordus Lanamana*, Imaculata Fatima \\ Agriculture Faculty, Flores University, Ende, Indonesia \\ Corresponding author: wlanamana@yahoo.com
}

\begin{abstract}
The objectives of this study were to: (1) analyze the effects of different land tenure status on soil conservation level and (2) analyze the soil conservation level on production and income of upland rice farming. This research was conducted in Mausambi Village, Maurole Subdistrict, Ende Regency. Considerations in choosing a research village were seen from: a) the number of farmers who pawned agricultural land b) the extent of dry land and critical land c) the high percentage of poor farmers d) centers of food crop production and e) areas vulnerable to erosion. The population of upland rice farmers in Mausambi village was 214 people and consisted of 36 sharecroppers, 32 mortgagors and 146 owners. The method of sampling is cluster sampling, where this technique is a technique of selecting a sample from groups, small units or clusters. The sample size was calculated using Parrel formula. The sample size of land ownership status was 92 owners, 34 sharecroppers and 21 mortgagors. The analysis method used was multiple linear regression by including dummy variable of land tenure status and quantitative descriptive analysis. The result of the analysis shows that the farmers on land tenure status of owner are better in doing soil conservation efforts when compared to farmers on land tenure status of sharecropper and mortgagor. Owner dummy variable significantly affected the soil conservation level at $99 \%$ significant level. The positive sign means that the soil conservation level score on owner land tenure status is higher than the owner land tenure status of sharecropper and mortgagor. This is because in the owner farmers, the responsibility of soil conservation is higher than the farmers on other land tenure status. The well-done soil conservation efforts provide effect on the production and income of upland rice farming. The result of the research also shows that the land in the research site has not experienced severe erosion and soil conservation has been conducted but not maximized yet, especially on the aspect of contour farming, terrace treatment, terrace-strengthening plants, and tillage.
\end{abstract}

Keywords: land tenure status, conservation, income

Cite this as: Lanamana, W., \& Fatima, I. 2018. Effects of Different Land Status on Conservation Land and Income of Upland Rice Farming in Mausambi Village, Maurole Subdistrict, Ende Regency. Caraka Tani: Journal of Sustainable Agriculture. 33(2), 126-135. doi: http://dx.doi.org/10.20961/carakatani.v33i2.21704

\section{INTRODUCTION}

An interesting phenomenon found in the Mausambi village, Ende regency, East Nusa Tenggara Province is the existence of three different land tenure status, land tenure status sharecropper, mortgagor and owner. Sharecropping is an agricultural system where a landowner allows other people (sharecropper) to use the land in return for a share of the agricultural products. Mortgage is a transfer of rights from the landowner to another party that acts more as a collateral of the money borrowed by the landowner to the money owner. The land is used as collateral for the amount of borrowed funds to be returned. During the mortgage term, the

\footnotetext{
* Received for publication June 29, 2018

Accepted after corrections September 28, 2018
} 
mortgaged farmland is used by the money owner for farming activities. In this case, the money owner acts as mortgagor and landowner as mortgagee.

Theoretically, different land tenure status will determine the farmer behavior in doing soil conservation, and the level of farming diversity. Farming by considering soil conservation will ensure the stability of production and income. The above conception is in line with Holden et al. (2009) opinion that land tenure right may increase farmer participation in land conservation. Recognition of land tenure (certificate) is a useful evidence to secure ownership. Land tenure security has increased land investment, such as annual crop planting, land conservation management improvement and land productivity increase. Land certification can increase the use of production inputs such as organic and inorganic fertilizer, and others. In line with Holden et al. (2009), a study conducted by Mustadjab (1994) provides further explanation that different tenure status significantly affects farmer behavior in soil conservation on dryland farming.

The importance of the study on soil conservation is due to the data found in the research site such as Mausambi village area that has a relatively low annual rainfall but with high intensity, has slope of 8-15\%, shallow soil solum and coarse soil texture. In such area, erosion of dryland agro-ecosystems may occur. Morgan (2005) explains that if the land is dry and the rainfall intensity is high, the soil aggregate will break rapidly, soil infiltration will decrease, the surface becomes slippery, and surface flow is large enough even though rainfall is only a few $\mathrm{mm}$ only. In slopes, the risk of erosion is quite significant, however providing shelter to the soil in the form of terracing, contour farming, and the utilization of organic fertilizers by in situ are wise actions in saving the environment particularly in overcoming land degradation (de Neergaard et al., 2008; Gardner and Gerrard, 2003; Nyssen et al., 2009).

According to Tiwari et al. (2008), in addition to the availability of various conservation technologies that can be selected and applied, if the conservation, adoption rate is low, then the decline in soil fertility will continue. This condition will cause soil erosion, decreased soil fertility, and in the long run will affect the productivity of agricultural products (Wudianto, 2009). From a study conducted by (Stocking,
2004), the effect of erosion on productivity is very dependent on the profile of the land. The effects of erosion on crop production vary greatly depending on plant species, land type, micro climate, topography and agricultural management systems (Lal and Moldenhauer, 1987). The same thing has been proven by Bishop and Allen (1989).

Research on the effects of erosion on land productivity in Indonesia is found in the results of research conducted by Abas et al. (2003). By applying several conservation technologies according to the land condition on dryland farming, land productivity can be increased, and it as can be seen from the erosion rate decreasing from 21.80 t/ha to 11.10 - $20 \mathrm{t} / \mathrm{ha}$ where the soil becomes fertile. Pande et al. (2011) explain that land degradation and erosion problems have attracted the attention of policy makers for a long time. The average annual loss of nutrients from land caused by erosion is estimated at 5.37-8.4 million tons.

Regarding the upland rice farming in Mausambi village, it is necessary to apply conservation farming system. This is because if the sloping land is used in farming, it will easily suffer from erosion. Conservation farming is a technology that aims to overcome the problem of environmental damage and agroecosystem (Pranadji, 2004). Conservation farming can prevent excessive erosion on sloping agricultural land and maintain soil fertility to protect land resource and environmental sustainability.

The farmer problems of upland rice farming in Mausambi village is they have not fully implemented the conservation farming properly that actually can increase the production and productivity of farming land, which ultimately increase the farmer income. Although the farmers want sustainable high productivity and income in upland rice farming, they have not completely believed that conservation farming can improve crop productivity. The farmers will easily implement conservation farming if they already know the results and benefits first. This encourages the researcher to conduct a research by looking at it from different land tenure status.

Referring to the background and problems faced, the research problem is as follows: "How far the Different Land Tenure Status Affects the Soil Conservation Level and Upland Rice Farming Income. The objectives of this study are to: (1) analyze the effects of different land tenure 
status on the soil conservation level and (2) analyze the soil conservation level on production and income of upland rice farming.

\section{MATERIALS AND METHOD}

This research was conducted in Mausambi Village, Maurole Subdistrict, Ende Regency, from October to December 2014. Considerations in choosing a research village were seen from: a) the number of farmers who pawned agricultural land b) the extent of dry land and critical land c) the high percentage of poor farmers d) centers of food crop production and e) areas vulnerable to erosion.

The population of upland rice farmers in Mausambi village was 214 people and consisted of 36 sharecroppers, 32 mortgagors and 146 owners. The method of sampling is cluster sampling, where this technique is a technique of selecting a sample from groups, small units or clusters. The sample size is calculated using a formula (Parel et al., 1973).

$$
\mathrm{n}=\frac{\mathrm{N} \mathrm{Z}^{2} \sigma^{2}}{\mathrm{Nd}^{2}+\mathrm{Z}^{2} \sigma^{2}}
$$

Information:

$$
\begin{aligned}
\mathrm{n}= & \text { sample size } \\
\mathrm{N}= & \text { population size } \\
\mathrm{D}= & \text { minimum deviation }=0.05 \\
\mathrm{Z}= & \text { confidence level } 95 \%=1.96 \text { according to } \\
& \text { distribution table } \mathrm{Z} \\
\sigma^{2}= & \text { variance in the population of farmland rice } \\
& \text { field }
\end{aligned}
$$

If the expected maximum deviation of $5 \%$ of the population variance is estimated from the variance of the sample of the farmland rice field area, then the sample size in each land tenure status is as follows in Table 1 .

Table 1. Population Size and Sample Size Per Land Mastery Status

\begin{tabular}{clccc}
\hline No. & \multicolumn{1}{c}{ Land Mastey Status } & Population Size & Sample Varians & Sample Size \\
\hline 1. & Owner & 146 & 0,16092 & 92 \\
2. & Sharecropper & 36 & 0,45069 & 34 \\
3. & Mortgagor & 32 & 0,04207 & 21 \\
& Total & 214 & & 147 \\
\hline
\end{tabular}

First, the analysis of soil conservation level on different land tenure status used quantitative descriptive analysis. Measurement of soil conservation level was conducted by scoring. The application of soil conservation technology was measured from 7 variables used to indicate the level of soil conservation farming application. The selection of 7 conservation technologies was in accordance with the land condition at the research site. This is in line with the idea of Lichtenberg and Smith-Ramírez (2011), that farmers manage different lands from the lands managed by other farmers in terms of productivity level and erosion resistance, so that the options for types of land conservation are varied. Similarly, farmer participation in land conservation may differ across regions according to the land type, land area, off farm and non-farm availability, and the presence of government programs (Chang and Boisvert, 2009). The 7 conservation technologies applied in this study included: 1) terrace treatment, 2) planting of terrace strengthening plants, 3) tillage, 4) contour farming, 5) crop rotation, 6) drainage construction, and 7) the use of manure. Each research variable was assigned different weight based on the importance level of the variable applied. The farmers were given 7 questions, the answer of each question was given a value in integer of 1, 2, 3, 4, 5. The final score obtained from the measurement of soil conservation level was the result of weight multiplication by value. To analyze the second objective, multiple linear regression analysis was used by including dummy variable of land tenure status. The mathematical formula of multiple linear regression was as follows:

$$
\mathrm{Y}=\beta_{0}+\beta_{1} \mathrm{X}_{1}+\beta_{2} \mathrm{X}_{2}+\beta_{3} \mathrm{X}_{3}+\mathrm{Ej} \mathrm{Dj}+\mathrm{U}
$$

Description:

$\mathrm{Y}=$ Soil conservation level

$\mathrm{X}_{1}=$ Household income variable

$\mathrm{X}_{2}=$ Farming period variable

$\mathrm{X}_{3}=$ Total family member variable

$\mathrm{Dj}=$ Dummy variable of land tenure status (D1= 1 for owner status, D1= 0 for other land tenure status; D2 $=1$ for land tenure status of sharecropper, D2 $=0$ for land tenure status of mortgagor). 


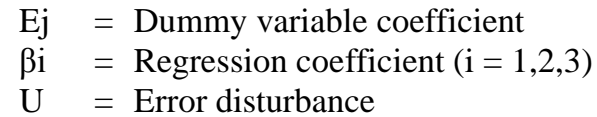

Prior to the multiple regression model estimation, the data used must be ensured to be free from classical assumptions deviations for normality, multicollinearity and heteroscedasticity. When the classical assumptions were met, the OLS estimator of the regression coefficient was BLUE (Best Linear Unbiased Estimator). The third objective was analyzed using descriptive analysis.

\section{RESULT AND DISCUSSION}

Analysis of the effect of different land tenure status on the level of land conservation

The component of soil conservation technology used to see the level of conservation implementation carried out by farmers consists of 7 components including; 1) terrace treatment, 2) planting of terrace strengthening plants, 3) tillage, 4) contour farming, 5) crop rotation, 6) drainage construction, and 7) the use of manure.

For the components of the terrace treatment, tillage, and contour farming, if the farmer applies it perfectly, then the score obtained are 20 , and vice versa if it approaches the value 4 then this shows the more imperfect application of soil conservation. The components of terrace strengthening plant, drainage construction, and using manure, if applied perfectly the score obtained are 15 , and vice versa is close to 3 , while for the crop rotation if it is applied perfectly the score obtained are 10, and vice versa approaches 2 . The data in Table 2 . shows the different levels of soil conservation application to the three land tenure status, from excellent to bad category.

Table 2. Average Level of Soil Conservation Application in the Three Land Tenure Statuses of Owner, Sharecropper, and Mortgagor.

\begin{tabular}{|c|c|c|c|c|c|c|}
\hline \multirow{3}{*}{$\begin{array}{c}\text { Component of Soil } \\
\text { Conservation Technology }\end{array}$} & \multicolumn{6}{|c|}{ Land Tenure Status } \\
\hline & \multicolumn{2}{|c|}{ Owner } & \multicolumn{2}{|c|}{ Sharecropper } & \multicolumn{2}{|c|}{ Mortgagor } \\
\hline & $\begin{array}{l}\text { Average } \\
\text { Score }\end{array}$ & Category & $\begin{array}{l}\text { Average } \\
\text { Score }\end{array}$ & Category & $\begin{array}{l}\text { Average } \\
\text { Score }\end{array}$ & Category \\
\hline Terrace Treatment & 13.7 & B & 11 & $\mathrm{~J}$ & 13.3 & B \\
\hline $\begin{array}{l}\text { Terrace Strengthening } \\
\text { Plant }\end{array}$ & 10 & B & 6.75 & $\mathrm{~J}$ & 8.85 & B \\
\hline Tillage & 15.9 & B & 8.67 & $\mathrm{~J}$ & 11.4 & $\mathrm{~J}$ \\
\hline Contour Farming & 16.5 & SB & 16.7 & SB & 17.5 & SB \\
\hline Crop Rotation & 3.98 & SJ & 3.67 & $\mathrm{~J}$ & 3.62 & $\mathrm{~J}$ \\
\hline Drainage Construction & 10.2 & B & 7.38 & $\mathrm{~J}$ & 8.57 & $\mathrm{~J}$ \\
\hline $\begin{array}{l}\text { Use of Organic and } \\
\text { Inorganic Fertilizer }\end{array}$ & 11.6 & B & 3.5 & SJ & 6.14 & $\mathrm{~J}$ \\
\hline Total Score & 82.01 & Good & 56.14 & $\mathrm{Bad}$ & 69.47 & $\mathrm{Bad}$ \\
\hline
\end{tabular}

Description: $\mathrm{SB}=$ Excellent, $\mathrm{B}=$ Good, $\mathrm{J}=$ Bad, $\mathrm{SJ}=$ Worst.

The results show that the total score on land ownership status is in good category, while the land tenure status of sharecropper and mortgagor are in bad category.

\section{Terrace Treatment}

The research site has a slope of $8-15 \%$, so the attention to the conservation technology of terrace making becomes very important. The terrace quality on land tenure status was 50 percent more than the perfect terrace quality, and on the land tenure status of mortgagor it can be categorized as good. It was different from the terrace quality on the land tenure status of sharecropper that was in bad category. Differences in terrace treatment are due to farmer knowledge on the importance of conservation, and the level of formal education. Owner farmers have a wider land and a higher level of formal education than the sharecroppers and mortgagors. This is in line with the opinion of Tiwari et al. (2008); Chang and Boisvert (2009); Lichtenberg and SmithRamírez (2011); Pande et al. (2011); and Asafu-Adjaye (2008), that farmer participation partially increases in the soil conservation with high number of land area owned. Mugniesyah and Mizuno (2001), also explained that the 
education level affects farming work in determining the production input in connection with the use of organic and inorganic fertilizers.

\section{Terrace Strengthening Plants}

Terrace strengthening plants specifically serve to strengthen the terrace building in order to prevent landslides during the rainy season. In addition, the terrace strengthening plants serves to improve the chemical and physical properties of the soil. The greater the terrace percentage on farmer land planted with the strengthening plants, the higher the conservation score or the more complete the application of technology components (Hidayat, 2007). In the three land tenure statuses, the highest score for terrace strengthening plants components was on land tenure status of owner. The average difference in scores was due to differences in knowledge about the importance of terrace strengthening plants.

\section{Tillage}

The tillage quality from the conservation aspect on the three land tenure statuses illustrates that land tenure status of owner was in good category whereas the farmers in the land tenure status of sharecropper and mortgagor were in bad category. This is due to differences in knowledge aspects about soil conservation, environmental awareness, soil and water, and the ability to obtain organic materials, especially organic and inorganic fertilizers.

\section{Contour Farming}

Contour farming has been practiced long enough by the community in the research site, because the topography of the research area is hilly. In the research site, the average score for the component of contour farming on the three land tenure statuses did not have striking difference, the three are in very good category.

\section{Crop Rotation}

In recent years, most of the farmers in the research site on the three land tenure statuses did not run the crop rotation system, due to the total rainy days and months that are uncertain and very short. As a result, the average score for the crop rotation component was in worst and bad category.

\section{Drainage Construction}

Farmers on land tenure status of owner pay more attention to the drainage quality when compared with farmers on land tenure status of sharecropper and mortgagor. This is due to differences in knowledge and skills as well as non-formal education received specifically on conservation technology.

\section{Use of Organic and Inorganic Fertilizer}

In the use of organic and inorganic fertilizers, the farmers on land tenure status of owner were in good category due to their ability to buy inorganic fertilizer. The results of the study found that most owner farmers raise cattle and the manure is used for organic fertilizer. Moreover, there are only a few sharecroppers and mortgagors who raise cattle, so the organic fertilizer used by the sharecroppers and mortgagors is obtained from the family or neighbors.

From the explanation regarding the application of soil conservation technology, it can be concluded that the farmers have not applied it maximally. Therefore, they need awareness to apply conservation farming according to the rules applicable for sustainability of productivity and increase in upland rice farming income.

\section{Analysis of the relationship between the level of soil conservation with production and income of field rice farming.}

The analysis result of the effects of land tenure status on the soil conservation level using multiple linear regression analysis is presented in Table 3. The classical assumption deviation test shows that the data is normally distributed, the multicollinearity symptoms are not serious, and there is no heteroscedasticity symptoms. 
Table 3. Regression Analysis of Land Status Effect on Soil Conversation Level

\begin{tabular}{lccc}
\hline \multicolumn{1}{c}{ Variabel Regression } & Coefficient & T count & P Value \\
\hline Household Income & $4.437 \mathrm{E}-7^{* * * *}$ & 4.69 & 0.002 \\
Farming Period & $-0.722^{* * *)}$ & -2.75 & 0.011 \\
Total Family Members & $3.251^{* * *)}$ & 4.01 & 0.000 \\
D1 Owner & $8.296^{* * *}$ & 3.19 & 0.002 \\
D2 Sharecropper & $-11.879^{* * *}$ & -4.90 & 0.000 \\
\hline
\end{tabular}

$\mathrm{F}_{\text {count }}=55.490$

$\mathrm{R}^{2} \quad=0.66$

Description

1. Dependent variabel of soil conservation level.

2. $\mathrm{F}_{\text {table }}(\alpha=0.01, \mathrm{df} 1=5, \mathrm{df} 2=141)=3.149$

3. $\mathrm{T}_{\text {table }} \alpha 0.01=(0.01, \mathrm{df} 99)=2.35$

$\mathrm{T}_{\text {table }} \alpha 0.05=(0.05, \mathrm{df} 95)=1.66$

$\mathrm{T}_{\text {table }} \alpha 0.10=(0.10$, df 90$)=1.32$

4. ${ }^{* * *)}$ real on $\alpha$ by $1 \%$

${ }^{* * *}$ real on $\alpha$ by $5 \%$

${ }^{*)}$ real on $\alpha$ by $10 \%$

The sig value in the owner dummy variable was 0.002 , the sig value was smaller than the probability value of 0.01 . $\mathrm{T}_{\text {count }}$ value $3.19>\mathrm{T}_{\text {table }}$ value 2.35 . It can be interpreted that the owner dummy variable significantly affected soil conservation level at significant level of $99 \%$. The positive sign means that the soil conservation level score on land tenure status of owner was higher than the land tenure status of sharecropper and mortgagor. This is because in owner farmers, the responsibility for soil conservation was higher than the farmers on the land tenure status of sharecropper and mortgagor. The land is a gift of God that must be preserved for the present and future life.

The sig value in the dummy variable was 0.000 , the sig value was greater than the probability value of 0.01 . $\mathrm{T}_{\text {count }}$ value $4.90>\mathrm{T}_{\text {table }}$ value 2.35 . This shows that the sharecropper dummy variable provides significant effect on soil conservation level. The negative sign on the dummy variable indicates that the soil conservation level score on the land tenure status of sharecropper is lower than the land tenure status of mortgagor, while the soil conservation level score on the land tenure status of mortgagor is lower than the land tenure status of owner. This is probably because the farmers on the land tenure status of sharecropper and mortgagor are immigrants, not native people in Mausambi village, so the responsibility for nature/land conservation is lower. The sense of belonging to nature/land is not as large as the owner farmers, so the orientation is more likely to produce production/income in short term.

Data in Table 4 shows the relationship between the levels of soil conservation application by farmers with the average production of upland rice farming in each category of worst, bad, good and excellent. Here, the production level in each category can be found.

Table 4. Average Production of Upland Rice Farming in Four Categories of Level of Soil Conservation Application

\begin{tabular}{lcc}
\hline $\begin{array}{c}\text { Category of } \\
\text { Soil Total } \\
\text { (People) }\end{array}$ & $\begin{array}{c}\text { Conservation } \\
\text { Application }\end{array}$ & $\begin{array}{c}\text { Average } \\
\text { Production } \\
\text { Kg/ha/year) }\end{array}$ \\
\hline Worst & - & - \\
Bad & 57 & 1570 \\
Good & 89 & 2475 \\
Excellent & 1 & 2850 \\
\hline
\end{tabular}

The results show that no upland rice that was found to be worst in applying conservation technology. In the bad category conservation level there were 57 farmers with an average production of $1570 \mathrm{~kg} / \mathrm{ha} /$ year. In good conservation level category, there were 89 farmers with average production of $2475 \mathrm{~kg} / \mathrm{ha} /$ year, while in excellent category there was 1 farmer with production achievement of 2850. This data shows that the higher level of soil conservation, the higher the production achievement of upland rice farming. This empirical fact should be the concern of the community and the government with respect to the policy that must be taken as an effort to maintain the availability of food in each farmer household. According to Lynch and Musser (2001), productivity issues, food security, and peace value are very important in determining policy and research in securing agricultural land. Furthermore, Gardner (Lynch \& Musser, 2001) suggests four benefits that can be gained from maintaining agricultural land productivity: (1) food security at local and national level, (2) 
employment in agro-industries sector, (3) efficient use of rural land and urban areas, and (4) protection or preservation of environment and rural security. In this case, Chouinard et al. (2008) also state that the United States Government plays an active role in implementing land conservation programs. It was reported that the United States Government agricultural budget since 2002 reached more than $\$ 38$ billion for conservation programs. The financing cooperation or financing sharing in the land conservation program is carried out between the government and the landowner. Bastos and Lichtenberg (2001) also suggest that promising land conservation activities will increase the production and income of farmers.
The data in Table 5 shows that the upland rice farmers is in excellent category in applying the soil conservation and the average income is higher than the upland rice farmers in good and bad category. The production level obtained by farmers in each category is also very different. This indicates that the production level obtained by farmers determines the difference in upland rice income in each category of soil conservation level. The production cost of upland rice farming for farmers who are categorized excellent is greater than good and bad category. Although the production cost is large, the income is also greater, meaning that the additional revenue of upland rice farming of the farmers in excellent category is still greater than the additional production cost.

Table 5. Average Revenue, Total Cost and Revenue of Paddy Farming Category of Soil Conservation Level Application of Excellent, Good, Bad and Worst.

\begin{tabular}{lcccc}
\hline \multirow{2}{*}{\multicolumn{1}{c}{ Description }} & \multicolumn{4}{c}{ Category of Soil Conservation Level Application } \\
\cline { 2 - 5 } & Excellent & Good & Bad & Worst \\
\hline Revenue (IDR/ha) & 13.252 .500 & 11.436 .168 & 7.202 .453 & - \\
Total Cost (IDR/ha) & 7.921 .125 & 7.055 .654 & 5.157 .837 & - \\
Income (IDR/ha) & 5.331 .375 & 4.380 .514 & 2.044 .616 & - \\
\hline
\end{tabular}

Income differences in each category in accordance with the general idea shows that if farmers practice conservation farming in the long term, it will affect the farming income. This idea is in line with a research by Katharina (2007) on potato commodities indicating that farming with the application of conservation technology in a long term will earn higher income than farmers who do not pay attention to conservation efforts. Similarly, a research conducted by Sinukaban (2010) shows that the use of conservation farming has been able to reduce the rate of erosion and increase farmer income.

Darmadi et al. (2014) conducted a study to analyze the effect of the level of implementation of conservation farming on the costs, production, and income of vegetable farming. This research was conducted in Jurang Kuali Hamlet, Sumber Brantas Village and Junggo Hamlet, Tulungrejo Village, Bumiaji District, Batu City, East Java Province. By using scoring analysis and simple and multiple linear regression analysis, the results show that the higher the implementation of conservation farming in vegetables will increase farmers' income. Research conducted by Fahriyah et al. (2013) shows the same explanation that by implementing good conservation farming, farm income can increase. Research conducted by Olarinde et al. (2011), in Africa also explained that the application of soil and water conservation technology can increase the total value of production by $17-24 \%$ per farm household.

Some researches to obtain information about the factors that influence farmers in implementing soil conservation efforts are carried out by AsafuAdjaye (2008) in Fiji. The results showed that the factors that significantly influence aging, education, ethnicity, net income, land size and land type. According to Mazvimavi and Twomlow (2009) in 2004, the International Crops Research Institute for the Semi Arid Tropics (ICRISAT) conducted a study that aimed to determine the factors that influence the implementation of conservation farming in Zimbabwe, the results showed that institutional support and agroecological location have a strong influence on the intensity of the implementation of conservation farming. Hettiarachchi and Gunatilake (2000) in the research in Walawe Hulu Srilanka watershed, illustrating the size of agricultural land and asset levels significantly influence the decision of farmers in implementing soil conservation. Some of these non-technical factors may be considered by farmers in applying 
conservation farming on dry land with a certain slope

The interesting finding of this research is that the farmers are generally reluctant to practice soil conservation farming due to the high cost if the land is not owned by them. Soil conservation efforts are still carried out at the research sites because traditional values are still maintained until now, particularly the values of harmony between nature, human and the Creator as well as the value of community work. In local people thinking, nature is a place where people put their hope in life, so that the existence of nature is not to be dominated, exploited/destroyed, and by community work the labor cost becomes cheaper. This is in line with what Chouinard et al. (2008) think that the farmer motive for land conservation can be varied, such as economic motive in order to increase land productivity and farm income or social and cultural reasons of local communities.

\section{CONCLUSIONS AND SUGGESTION}

\section{Conclusions}

There are differences in the application of the 7 soil conservation technologies by farmers of the three tenure statuses. In applying soil conservation technology, the farmers with tenure status of land owner are in the good category, whereas farmers with land tenure status of sharecropper and mortgagor are in bad category. The well-done soil conservation efforts bring effect on the production and income of upland rice farming. Farmers who carry out conservation farming well, get higher farming production and income than do farmers who run poor conservation farming.

\section{Suggestion}

Suggestions that can be given to farmers in the research site is they need to conduct technical coaching in a planned and sustainable way in connection with the application of conservation technology, specifically in making a good terrace, planting strengthening plants, proper tillage, drainage construction, and manure use.

\section{REFERENCES}

Abas, A., Soelaeman, Y., \& Abdurachman, A. 2003. Keragaan dan Dampak Penerapan Sistem Usaha Tani Konservasi terhadap Tingkat Produktivitas Lahan Perbukitan
Yogyakarta. Jurnal Litbang Pertanian, 22(2), 49-56. Retrieved from http://pustaka.litbang.pertanian.go.id/publikas i/p3222032.pdf\%0A

Asafu-Adjaye, J. 2008. Factors Affecting the Adoption of Soil Conservation Measures: A Case Study of Fijian Cane Farmers. Journal of Agricultural and Resource Economics, 33, 99117. https://doi.org/10.2307/41220616

Bastos, G. S., \& Lichtenberg, E. 2001. Priorities in Cost Sharing for Soil and Water Conservation: A Revealed Preference Study. Land Economics, 77(4), 533-547. https://doi.org/10.2307/3146939

Bishop, J., \& Allen, J. 1989. The on-site costs of soil erosion in Mali (English). Environment Department working paper; no. ENV 21. Washington, DC: World Bank. Retrieved from http://documents.worldbank.org/curated/en/35 6941468049761035/The-on-site-costs-of-soilerosion-in-Mali

Chang, H.-H., \& Boisvert, R. N. 2009. Distinguishing between Whole-Farm vs. Partial-Farm Participation in the Conservation Reserve Program. Land Economics, 85(1), 144-161. https://doi.org/10.3368/le.85.1.144

Chouinard, H. H., Paterson, T., Wandschneider, P. R., \& Ohler, A. M. 2008. Will Farmers Trade Profits for Stewardship? Heterogeneous Motivations for Farm Practice Selection. Land Economics, $\quad 84(1), \quad 66-82$. https://doi.org/10.3368/le.84.1.66

Darmadi, D. E., Mustadjab, M. M., \& Purnomo, M. 2014. Pengaruh Tingkat Penerapan Usahatani Konservasi Terhadap Produksi Dan Pendapatan Usahatani Sayuran Di Kecamatan Bumiaji Kota Batu. HABITAT, 24(3), 214 222. Retrieved from http://habitat.ub.ac.id/index.php/habitat/article /view/125

de Neergaard, A., Magid, J., \& Mertz, O. 2008. Soil erosion from shifting cultivation and other smallholder land use in Sarawak, Malaysia. Agriculture, Ecosystems and Environment, 125(1-4), $182-190$. https://doi.org/10.1016/j.agee.2007.12.013

Fahriyah, Hanani, N., \& Sulistyono, A. 2013. Hubungan Tingkat Penerapan Usaha Tani Konservasi Terhadap Produktivitas dan 
Pendapatan Usahatani Wortel (Daucus Carota L) (Kasus Kecamatan Bumiaji, Kota Batu). Jurnal AGRISE Agricultural Socio-Economics Journal, 13(1), 42. Retrieved from http://agrise.ub.ac.id/index.php/agrise/article/ view/37

Gardner, R. A. M., \& Gerrard, A. J. 2003. Runoff and soil erosion on cultivated rainfed terraces in the Middle Hills of Nepal. Applied Geography, 23(1), 23-45. https://doi.org/10.1016/S0143-

6228(02)00069-3

Hettiarachchi, N. D. G., \& Gunatilake, H. M. 2000. Factors Affecting the Use of Soil Conservation Measures by Upland Farmers in the Walawe River Watershed. Tropical Agriltural Research, 12, 255-264. Retrieved from http://dl.nsf.ac.lk/handle/1/11860

Hidayat, K. 2007. Respon Masyarakat Desa Terhadap Pembangunan Pertanian Berkelanjutan. Kasus di Daerah Aliran Sungai Brantas Hulu, Jawa Timur. Program Pascasarjana Universitas Brawijaya. Retrieved from

http://digilib.ub.ac.id/inlislite3/opac/detailopac?id=7700

Holden, S. T., Deininger, K., \& Ghebru, H. 2009. Impacts of low-cost land certification on investment and productivity. American Journal of Agricultural Economics, 91(2), 359-373. https://doi.org/10.1111/j.14678276.2008.01241.x

Katharina, R. 2007. Adopsi sistem pertanian konservasi usahatani kentang di lahan kering dataran tinggi Kecamatan Pangalengan Bandung. Retrieved from https://repository.ipb.ac.id/handle/123456789/ 40837

Lal, R., \& Moldenhauer, W. C. 1987. Effects of soil erosion on crop productivity. Critical Reviews in Plant Sciences, 5(4), 303-367. https://doi.org/10.1080/07352688709382244

Lichtenberg, E., \& Smith-Ramírez, R. 2011. Slippage in conservation cost sharing. American Journal of Agricultural Economics, 93(1), 113-129. https://doi.org/10.1093/ajae/aaq124

Lynch, L., \& Musser, W. N. 2001. A Relative Efficiency Analysis of Farmland Preservation
Programs. Land Economics, 77(4), 577-594. https://doi.org/10.2307/3146942

Mazvimavi, K., \& Twomlow, S. 2009. Socioeconomic and institutional factors influencing adoption of conservation farming by vulnerable households in Zimbabwe. Agricultural Systems, 101(1-2), 20-29. https://doi.org/10.1016/j.agsy.2009.02.002

Morgan, R. P. C. 2005. Soil Erosion and Conservation, 3rd Edition. Malden, MA 02148-5020, USA: Wiley-Blackwell. Retrieved from https://www.researchgate.net/file.PostFileLoa der.html?id=588d60dbf7b67e5c7449ba93\&as setKey $=$ AS\%3A455706806624256\%4014856 60378033

Mugniesyah, S. S. M., \& Mizuno, K. 2001. Gender, Poverty and Peasant Household Survival Strategies -A Case Study in Dry Land Village in West Java. In Proceeding of the 1st Seminar "Toward Harmonization between Development and Environmental Conservation in Biological Production" ( $\mathrm{p}$. 63). Tokyo: Graduate School of Agricultural and Life Sciences The University of Tokyo, JAPAN.

Mustadjab, M. 1994. Alokasi Sumber Daya Pertanian dan Usaha Konservasi Tanah Pada Usahatani Lahan Kering dengan Status Penguasaan Lahan Yang Berbeda. Universitas Padjajaran Bandung.

Nyssen, J., Poesen, J., \& Deckers, J. 2009. Land degradation and soil and water conservation in tropical highlands. Soil and Tillage Research, 103(2), 197-202. https://doi.org/10.1016/j.still.2008.08.002

Olarinde, L. O., Oduol, J. B., Binam, J. N., Diagne, A., Njuki, J., \& Adekunle, A. A. 2011. Impact of the adoption of soil and water conservation practices on crop production: baseline evidence of the sub Saharan Africa challenge programme. Middle East Journal of Scientific Research, 9(1), 28-40. Retrieved from

http://www.idosi.org/mejsr/mejsr9(1)11/5.pdf \%5Cnhttp://ovidsp.ovid.com/ovidweb.cgi?T= $\mathrm{JS} \& \mathrm{CSC}=\mathrm{Y} \& \mathrm{NEWS}=\mathrm{N} \& \mathrm{PAGE}=$ fulltext $\& \mathrm{D}$ $=$ caba6\&AN=20113380422\%5Cnhttp://sfx.li brary.wur.nl:9003/sfx_local?sid=OVID:cabad b\&id=pmid:\&id=doi:\&issn=1990- 
9233\&isbn $=\&$ volume $=9 \&$ issue $=1 \&$ sp

Pande, V., Kurothe, R., Singh, H. B., \& Tiwari, S. P. 2011. Incentives for soil and water conservation on farm in ravines of Gujarat: Policy implications for future adoption. Agricultural Economics Research Review, 24, 109-118. Retrieved from http://www.researchgate.net/publication/2273 65133_Incentives_for_Soil_and_Water_Cons ervation_on_Farm_in_Ravines_of_Gujarat_P olicy_Implications_for_Future_Adoption/file/ 60b7d5267648822788.pdf

Parel, C. P., Caldito, G. C., Ferrer, P. ., De Guzman, G. G., Sinsioco, C. S., \& Tan, R. H. 1973. Sampling Design and ProceduresPapers on survey research methodology. New York: Agricultural Development Council. Retrieved from https://books.google.co.id/books/about/Sampl ing_Design_and_Procedures.html?id=Dz_Un QEACAAJ\&redir_esc $=\mathrm{y}$

Pranadji, T. 2004. Strategi Pengembangan Teknologi Usahatani Konservasi Untuk Pembangunan Pedesaan Berkelanjutan. In Forum Penelitian Agro Ekonomi (Vol. 22, pp. 113-125).

https://doi.org/10.21082/fae.v22n2.2004.113125
Sinukaban, N. 2010. Pengelolaan lahan pertanian berbasis pembangunan berkelanjutan. Jurnal Hidrolitan Vol 1, 1(pertanian), 1-9. Retrieved from https://onlinejournal.unja.ac.id/index.php/hidrolitan/article/ view/406

Stocking, M. A. 2004. Erosion and soil productivity: a review. Norwich, UK. Retrieved from https://www.scopus.com/record/display.uri?or igin $=$ recordpage $\&$ eid $=2$-s2.0-

$18544394440 \&$ citeCnt $=5 \&$ noHighlight $=$ false \&sort=plf-

$\mathrm{f} \& \mathrm{src}=\mathrm{s} \& \mathrm{st} 1=$ Stocking \&st $2=\mathrm{M} \& \mathrm{nlo}=1 \& \mathrm{nlr}=$ $20 \&$ nls $=$ count -

$\mathrm{f} \& \mathrm{sid}=8 \mathrm{DB} 8 \mathrm{FFF} 2812947304336 \mathrm{C} 12844 \mathrm{~B} 82$

CBA.WXhD7YyTQ6A7Pvk9AlA\%3A4113

$\&$ sot=anl\&sdt=aut\&sl=

Tiwari, K. R., Sitaula, B. K., Nyborg, I. L. P., \& Paudel, G. S. 2008. Determinants of farmers' adoption of improved soil conservation technology in a Middle Mountain Watershed of Central Nepal. Environmental Management, 42(2), 210-222. https://doi.org/10.1007/s00267-008-9137-z

Wudianto, R. 2009. Mencegah Erosi. Jakarta: Penebar Swadaya. 